\title{
IUGG in the 21st century
}

\author{
Jo Ann Joselyn 1,*, Alik Ismail-Zadeh ${ }^{2,3}$, Tom Beer ${ }^{4}$, Harsh Gupta $^{5}$, Masaru Kono ${ }^{6, *}$, Uri Shamir ${ }^{7, *}$, \\ Michael Sideris $^{8}$, and Kathryn Whaler ${ }^{9}$ \\ ${ }^{1}$ Space Environment Center, National Oceanic and Atmospheric Administration, Boulder, Colorado, USA \\ ${ }^{2}$ Karlsruhe Institute of Technology, Institute of Applied Geophysics, Karlsruhe, Germany \\ ${ }^{3}$ Russian Academy of Sciences, Institute of Earthquake Prediction Theory and Mathematical Geophysics, \\ Moscow, Russia \\ ${ }^{4}$ Safe System Solutions Pty Ltd, Brunswick VIC, 3056, Australia \\ ${ }^{5}$ National Geophysical Research Institute, Hyderabad, India \\ ${ }^{6}$ Tokyo Institute of Technology, Tokyo, Japan \\ ${ }^{7}$ Israel Institute of Technology, Haifa, Israel \\ ${ }^{8}$ University of Calgary, Schulich School of Engineering, Department of Geomatics Engineering, \\ Calgary, Canada \\ ${ }^{9}$ University of Edinburgh, School of GeoSciences, Edinburgh, Scotland, UK \\ *retired
}

\author{
Correspondence: Alik Ismail-Zadeh (alik.ismail-zadeh@kit.edu) and \\ Jo Ann Joselyn (jjoselyn@earthlink.net)
}

Received: 11 November 2018 - Accepted: 7 January 2019 - Published: 16 April 2019

\begin{abstract}
The International Union of Geodesy and Geophysics (IUGG) has vigorously responded to a number of the natural, scientific, and technological challenges and driving forces that have marked the 21st century thus far. This paper reviews the actions of the Union that were precipitated by disasters caused by natural hazard events, climatic and environmental changes, and important scientific advances, as well as the opportunities to support International Years and other cooperative programs. This period has also given rise to a number of structural changes within the Union. IUGG added an eighth association, the International Association of Cryospheric Sciences, and inaugurated the new categories of affiliate and honorary memberships, introduced new grants, science education, and recognition programs, and formed new Union commissions on climatic and environmental change, data and information, planetary sciences, and a working group on history. Electronic communication was welcomed as a cultural norm. Overall, the development of the scientific landscape in the 21st century and a healthy future for the Union requires emphasis on fundamental Earth and space sciences as well as on transdisciplinary science to resolve urgent problems of society. IUGG will continue to evolve throughout the coming decades in step with the changing world of science and its international organizations, by responding to challenging problems as they arise.
\end{abstract}

\section{Introduction}

This is the last of three papers dedicated to the centennial history of the International Union of Geodesy and Geophysics (IUGG). The first paper (Ismail-Zadeh and Joselyn, 2019; current Special Issue) introduces the Union, presenting its mission, membership, structure, programs, products, and partners, and then presents an overview of the formation of the Union and its development until the beginning of WWII. The second paper (Joselyn and Ismail-Zadeh, 2019; current Special Issue) describes IUGG's evolution and its activities during the post-WWII era until the end of the 20th century.

Founded by nine scientific academies of the allied nations, the number of member countries increased to 35 by 1939 and to 76 by 1999, although some countries joined and left the Union over time; 22 general assemblies (and 2 extraordinary 
assemblies) were held in different international venues, and the number of delegates attending the general assemblies increased from a few dozen to more than 4000 scientists. Each General Assembly of the Union since the First General Assembly in 1922 until the XXII General Assembly in 1999 has been summarized by Ismail-Zadeh and Joselyn (2019) and Joselyn and Ismail-Zadeh (2019). The International Geophysical Year (IGY; 1957-1958) initiated by IUGG and its national members and co-sponsored by the International Council of Scientific Unions (ICSU; now the International Science Council - ISC) and the World Meteorological Organization (WMO) was an extraordinary global scientific effort. It was one of the most successful scientific and outreach programs of the last century, bringing together natural and social scientists, engineers, politicians, media, and society. After the IGY, international multi- and inter-disciplinary scientific campaigns became commonplace; many new international scientific bodies were formed by ICSU with IUGG's participation; many geophysical observatories were founded; and the Union initiated and rigorously supported a number of international scientific programs (see Table 1 in Joselyn and Ismail-Zadeh, 2019).

This paper starts with a review of the activities of the Union related to fostering research on disaster risks, and climatic and environmental changes. It discusses IUGG's involvement in and support of International Years and other cooperative programs during almost 2 decades of the 21st century (at the time of writing). A number of structural changes occurred within the Union, the most important of which was the establishment of the International Association of Cryospheric Sciences, an eighth association of the Union, in 2007. IUGG agreed to establish the new categories of affiliate and honorary memberships, introduced new grants, geoscience education, and recognition programs, and formed new Union commissions on climatic and environmental change, data and information, planetary sciences, and a working group on history. The development of the scientific landscape in this century and a healthy future for the Union requires emphasis on fundamental sciences as well as on transdisciplinary science to help in solving urgent problems of society.

\section{Promoting natural hazards and disaster risk science}

The early years of the 21 st century have been marked by a number of extreme natural events and associated great disasters that have strongly influenced both public policy and scientific research (e.g., Cutter et al., 2015). These include earthquakes (e.g., 2004 Aceh-Sumatra in the Indian Ocean in 2005, Kashmir (Pakistan) in 2005, Wenchuan (China) in 2008, Haiti in 2010, Tohoku (Japan) in 2011, and Nepal in 2015) that triggered tsunamis and/or landslides; floods (e.g., in western and central Europe in 2002, China in 2007; Tai- wan and Philippines in 2009); and cyclones and hurricanes (e.g., hurricanes Katrina in 2005 and Harvey in 2017, both in USA; cyclone Nargis in Myanmar in 2008). These and other extreme events have resulted in tragic losses of life and infrastructure.

Several of the IUGG Associations and inter-Association commissions address potentially violent geophysical processes. In August 2000, IUGG created the Union Commission on Geophysical Risk and Sustainability (GRC) specifically to study the likelihood of hazards, their impacts and consequences as a result of the vulnerability of societies, and to recommend measures for adaptation and mitigation. Thus, the commission was ready when a magnitude 9.2 earthquake struck on 26 December 2004 off the western coast of northern Sumatra, South Asia. The resulting tsunamis inundated the coastal zones around the Indian Ocean and resulted in losses of more than 230000 lives across many countries. A few months before the event, the GRC had released the first catalog of tsunamis in the Indian Ocean to the public. The GRC, in cooperation with the IUGG interAssociation Tsunami Commission, prepared a statement that was sent to the Secretariat of the United Nations International Strategy for Disaster Reduction (UNISDR) and presented by IUGG Vice President Tom Beer to the United Nations World Conference on Disaster Reduction in Kobe, Japan (January 2005). This statement was revised and adopted as IUGG Resolution 8 "Reduction of Risk from Natural Hazards" at the General Assembly in Perugia, Italy, in 2007 (IUGG Archives, 2007). Several IUGG Associations responded by convening workshops and symposia to study the relevant geophysical process and presented recommendations for observation, analysis and warning systems. On 12 January 2010, a strong earthquake of magnitude 7 struck Port-au-Prince, Haiti, and resulted in a death toll that was estimated to range from 100000 to 316000 . After the earthquake, on 29 January 2010, IUGG issued a special resolution, "Science on Natural Hazards and Environmental Disasters", urging the "international science community to quantify natural hazards and extreme events at all scales; to adopt integrative and comprehensive interdisciplinary approaches towards developing adaptation in order to decrease vulnerability; and to produce planning tools for disaster risk reduction at all scales." This and all other IUGG statements can be found on the IUGG website under Special Resolutions and Statements (http://www.iugg.org/about/special.php, last access: 29 January 2019).

A political consequence of scientific efforts to understand and predict natural disasters and inform society occurred in 2009 when the L'Aquila (Italy) Prosecutor's office indicted the members of the Abruzzi region's High Risk Committee for unintended murder for issuing statements to calm the population before the strong earthquake of 6 April that killed about 300 people. Believing that no scientist should be prosecuted for having expressed a scientific opinion based on available knowledge that is often necessarily limited, IUGG 
issued in June 2010 a statement on "Freedom to Conduct Science and Responsibilities of Scientists" highlighting the ICSU Principle of the Universality of Science. This principle encompasses freedom in relation to expressions of scientific ideas, hypotheses and forecasts, to conduct research using data, information, experiments and theories, and to communicate scientific results to the public through open publications and scientific conferences. Italy's Supreme Court finally cleared the committee's members in 2015, after a judicial process lasting more than 5 years (Cartlidge, 2015).

IUGG released two statements related to the eruptions of the Eyjafjallajökull volcano in Iceland that highlighted the importance of understanding the eruptive state of each of the world's active volcanoes for the safety and health of local residents as well as for air traffic and global climate. The first statement on Volcanic Ash Clouds (20 April 2010) was distributed at the Congressional Briefings on Reducing Volcano Risks in the U.S. Senate and the House of Representatives. The second statement on Volcanological and Meteorological Support for Volcanic Ash Monitoring (28 May 2010) was welcomed by the WMO Executive Board and the International Civil Aviation Organization (ICAO). Both statements can be found on the IUGG website, as specified above.

On 11 March 2011 a magnitude 9.0 earthquake occurred off the Pacific coast of Tohoku, Japan. It induced a catastrophic tsunami that hit the coasts of Tohoku and Kanto. The toll of dead and missing exceeded 18000 people and critically damaged a Japanese nuclear power plant. IUGG expressed heartfelt sympathy for the victims, and again the GRC prepared a statement on the Great East Japan Earthquake and Tsunami that was adopted by the IUGG Bureau.

With the aim of strengthening international cooperation in disaster risk science, IUGG accepted a proposal by Secretary General Alik Ismail-Zadeh and initiated in 2010 an interdisciplinary international project entitled "Extreme Natural Hazards and Societal Implications - ENHANS" (http://www. icsu-geounions.org/enhans, last access: 29 January 2019), then co-sponsored by ICSU and several international and intergovernmental organizations. The major scientific results of the project were published in the IUGG volume Extreme Natural Hazards, Disaster Risks and Societal Implications (Ismail-Zadeh et al., 2014). The ENHANS project concluded that a reduction of disaster risk could be reached through indepth scientific research on the topic and through disaster risk assessments.

In 2011, IUGG President Harsh Gupta and Secretary General Alik Ismail-Zadeh submitted a resolution on disaster risk assessment to the 30th ICSU General Assembly. The ICSU Executive Board then opened global discussions on the need for an intergovernmental body for the assessment of disaster risk and directed the preparation of a multi-disciplinary report that was presented at the 31st ICSU General Assembly (2014). The Assembly applauded the initiatives on disaster risk assessment undertaken by the Integrated Research on Disaster Risk (IRDR) program, ICSU, the International So- cial Science Council (ISSC), and the UNISDR, as well as the international scientific unions and the Council's Regional Offices, and invited individual national members to support the proposed intergovernmental disaster risk assessment process. After the ICSU General Assembly, ICSU and ISSC formed a joint ad hoc group of experts, co-chaired by ICSU President Gordon McBean and IUGG Secretary General Alik IsmailZadeh, to prepare a synthesis report on disaster risk research and risk assessment to be presented at the United Nations Third Conference on Disaster Risk Reduction held in Sendai, Japan, in 2015 (Ismail-Zadeh and Cutter, 2015). The report was published before the conference, and its executive summary was distributed among the delegates of the conference at the request of the Russian Federation.

\section{Promoting climatic and environmental science}

Among the environmental problems IUGG addresses are climate, its variability and the contribution of $\mathrm{CO}_{2}$ emission to its change in order to save our planet for future generations; environmental pollution and its reduction in megacities to improve the quality of life; weather and water conditions to assist farmers during harvests and provide other indispensable ecosystem services; clean water and decontamination of polluted water to preserve and enhance human and ecosystem health; and pollution of oceans and seas, biodiversity and food security. Representing many disciplines of Earth and space sciences, IUGG has been continuously involved in projects and programs related to climatic and environmental changes and their impacts.

By the middle of the 20th century, the impacts of climatic and environmental changes were well understood by many experts involved in relevant studies and programs of ICSU or other international bodies (Weart, 2012). The experts proposed that a major scientific program on climate be established, and after long debates, the World Climate Research Programme (WCRP) was set up by WMO and ICSU in 1980 (later the Intergovernmental Oceanographic Commission of the United Nations Educational, Scientific and Cultural Organization (UNESCO) joined ICSU and WMO as a co-sponsor) in order to "determine the predictability of climate and to determine the effect of human activities on climate" (from the WCRP mission statement). IUGG experts contributed to the process of setting up the Intergovernmental Panel on Climate Change (IPCC) to help raise awareness of societies and politicians about climate change (Bolin, 2007). Among them was Bert Bolin (IUGG Bureau Member, 1963-1967), who was involved in setting up and development of the Global Atmospheric Research Programme (Ashford, 1982) as well as WCRP, the International GeosphereBiosphere Programme, and IPCC, becoming its first Chairman (Rohde, 2013). Many IUGG experts shared the 2007 Nobel Peace Prize with the IPCC and Al Gore (Ismail-Zadeh, 2016). 
In 2012, IUGG established the Union Commission on Climatic and Environmental Change (CCEC) to promote the advancement of scientific understanding of climatic and environmental change, to boost research in reducing uncertainties in climate and environmental models, to define criteria for collaborative transdisciplinary research on climate and environmental change, to fulfill the objectives of IUGG and its Associations, to provide an all-Union perspective on climatic and environmental change, and to make available the knowledge and insights developed through scientific research for the benefit of society and planet Earth, including consideration of the science of global change, related vulnerability and impacts, and potential responses. CCEC provides a focus for IUGG scientific expertise in climate and environment related areas across the breadth of all IUGG disciplines. CCEC enables the breadth of IUGG expertise to be brought to bear at the global level through collaborating with, and underpinning the work of ICSU and other international organizations. It also enables the geographic spread of IUGG expertise to be brought to bear at the local level through involvement with national bodies in the organization of scientific meetings and other activities. The research on the climatic and environmental change and high-impact of weather and climate events by the members of the CCEC and the Climate Commission of the International Association of Meteorology and Atmospheric Sciences (IAMAS) of IUGG was published as an IUGG volume by Cambridge University Press (Li et al., 2016). The work of CCEC demonstrated how multi- and inter-disciplinary research outputs from the geoscience community can be applied to tackle the physical and societal impacts of climate change and to contribute to Future Earth, a major environmental program initiated by the International Science Council (Beer et al., 2018).

At the request of IUGG Secretary General Alik IsmailZadeh, 14 international experts of the International Association on the Physical Sciences of the Oceans (IAPSO) of IUGG together with those of the ICSU Scientific Committee on Oceanic Research (SCOR) developed a synthesis report, Future of the Ocean and its Seas (Williamson et al., 2016), for science policymakers of seven economically developed countries (G7 Science Ministers). The report was prepared for the annual meeting of G7 Science Ministers held in Tsukuba, Japan, in May 2016, as a response of nongovernmental scientific organizations to the concern of the policymakers expressed at their meeting in Berlin, Germany, in September 2015. The experts addressed topics related to plastic pollution of the marine environment, deep-sea mining and its ecosystem impacts, ocean acidification, deoxygenation, ocean warming, biodiversity loss, and marine ecosystem degradation.

\section{International Years}

The United Nations is the body that declares "International Years" (IY). The process requires both non-governmental and governmental support at the highest levels. To mark 50 years after the remarkable International Geophysical Year (1957-1958), 3 related IYs to conduct scientific programs were successfully proposed. These were the International Year of Planet Earth (IYPE), the International Polar Year (IPY), and the International Heliophysical Year (IHY). A fourth international program, the electronic Geophysical Year (eGY), joined the others to support this scientific focus. IUGG and the Union Associations were active in developing these programs and provided leadership and support for each. The four programs met in 2008 and issued the Tsukuba Declaration (http://www.egy.org, last access: 29 January 2019), noting that scientific cooperation among the global science community, national academies of sciences, research funding agencies, industry, national governments, and inter-governmental bodies provide society and its leaders with the best possible information to make decisions on a sustainable future for humankind. Table 1 lists the International Years initiated and/or supported by IUGG since 2001.

\section{GeoUnions}

In 2004, representatives of several ICSU International Scientific Unions dealing with Earth and space sciences met in Paris to establish a partnership to better promote the geosciences worldwide, to communicate and to coordinate scientific activities of individual unions, and to gain recognition by ICSU bodies, the United Nations organizations, and other global stakeholders. The partnership has endured as the GeoUnions. Current members are the International Astronomical Union, the International Cartographic Association, the International Geographical Union, the International Union for Quaternary Research, the International Society for Photogrammetry and Remote Sensing, IUGG, the International Union of Geological Sciences, the International Union of Soil Sciences, and the International Union of Radio Science.

The GeoUnions Steering Committee has developed a website (http://icsu-geounions.org, last access: 29 January 2019) to inform the scientific community about joint activities. The GeoUnions network has persisted and has proved powerful in fostering integrated interdisciplinary research. An example of one such collaboration is the Geoscience in Africa initiative, launched in 2003 by then IUGG President Uri Shamir, based on the recognition that geophysical processes are global and that African scientists suffer, more than others in the rest of the world, from shortage of resources, shortage of an adequate cadre of trained scientists, and lack of government recognition and support. Adopted as a science program of the GeoUnions, this effort supported the ICSU Regional 
Table 1. International Years initiated or supported by IUGG (2000-2019).

International Year of Planet Earth (IYPE; 2007-2010)

IYPE (http://yearofplanetearth.org, last access: 29 January 2019) was the first UN Year for Earth Sciences initiated and led by the International Union of Geological Sciences. In December 2005, the UN General Assembly proclaimed 2008 as the UN Year of Planet Earth - Earth Sciences for Society. IUGG had supported the drive toward IYPE since 2003. Nine science objectives and relevant teams were established: hazards (chaired by Tom Beer, IUGG President 2007-2011); groundwater; climate; oceans; Earth and health; resources; megacities; deep Earth; and soils. IUGG scientists were valued members of many of these teams. A series of monographs were published that report on each of these topics (https: //link.springer.com/bookseries/8096, last access: 29 January 2019).

International Polar Year

(IPY; 2007-2008)
Previous IPYs (1882-1883, 1932-1933, and IGY 1957-1958) successfully promoted unprecedented exploration and discoveries, and fundamentally changed how science was conducted in Polar Regions. The fourth IPY (http://ipy.org, last access: 29 January 2019) brought together tens of thousands of investigators to collect and analyze data in diverse disciplines in the physical, life, and social sciences, including engagement of the native communities. The IPY Data and Information Service (IPYDIS) addressed the challenge of data coordination. The IPYDIS participated in the IUGG-led Electronic Geophysical Year (eGY) and applied eGY principles to IPY data management. Building on the precedent set by the Antarctic Treaty, the data generated during the campaign have been archived in the Polar Information Commons, an open-access information resource about the Earth's polar regions (http://www.polarcommons.org, last access: 29 January 2019). Major publications and conferences emerged from the IPY. The final IPY conference, From Knowledge to Action, was held in Montréal, Canada in 2012.

Electronic Geophysical Year (eGY; 2007-2008)

Initiated by the International Association of Geomagnetism and Aeronomy (IAGA), the opening ceremony was held during the IUGG General Assembly in Perugia, Italy in 2007. The Electronic Geophysical Year (http://www.egy.org, last access: 29 January 2019) provided the international framework for mobilizing the science community to achieve a step increase in making past, present, and future geoscientific data readily, rapidly, conveniently, and openly available. The eGY promoted the development of a network of virtual observatories and focused on themes of electronic data location and access, permission and release of data, conversion of data into modern digital form, data preservation, outreach, and capacity building in developing countries, especially in Africa.

International Heliophysical Year (IHY; 2007-2008)

Several IAGA commissions participated in this broad international effort which addressed all aspects of the connected Sun-Solar system while also engaging the public, and students all over the world. It was coordinated with the UN Basic Space Science Initiative through their Office for Outer Space Affairs. The IHY Organizing Committees included 75 nations, and the activities involved representation from nearly all of the 192 United Nations member states. More information on the IHY and its legacy, the International Space Weather Initiative, can be found at: http://www.unoosa.org/oosa/en/ourwork/psa/bssi/ihy2007.html (last access: 29 January 2019).

International Year of Deltas

(IYD; 2013-2014)
This year focused on the value and vulnerability of river deltas worldwide. IYD was cosponsored by IUGG under the auspices of the International Association of Hydrological Sciences (IAHS) and the International Association for the Physical Sciences of the Oceans (IAPSO), who appointed liaisons to the IYD Scientific Committee. It was extended in 2015 to the International Decade of Deltas program. More information on the IYD: https://agupubs.onlinelibrary.wiley.com/doi/pdf/10.1029/2011EO400006 (last access: 29 January 2019).

Co-sponsored by IUGG, IYGU was initiated by the International Geographical Union and endorsed by ICSU, ISSC and the International Council for Philosophy and Human Sciences (CIPSH). IYGU aimed to build bridges between global thinking and local action by addressing sustainable development and fostering policies on critical global challenges such as climate change, food security and migration. In 2018, this year was extended to the International Decade of Global Understanding program. More information on the IYGU: http://www.global-understanding.info/ (last access: 29 January 2019). 
Office in Africa, and "eGYAfrica - better Internet connectivity for research and education institutions in Africa", and the ENHANS project noted above. Current key areas are disaster risk reduction and the International Year of Global Understanding (IYGU).

\section{IUGG structure}

A significant change to the IUGG structure in the 21st century was the addition of an eighth Association, the International Association of Cryospheric Sciences. The new Association had its origins in the IAHS International Commission on Snow and Ice (ICSI), formally established in 1948 but with roots extending back to 1894 . At the 2004 IUGG Executive Committee meeting, a Union Commission for the Cryospheric Sciences (IUGG/CCS) was proposed by IAHS and supported by IAMAS, IAPSO, and IAVCEI. The Commission began work on its proposed Association Statutes and By-laws, organized international symposia and planned scientific sessions for the 2007 IUGG General Assembly. In the meantime, changes in the IUGG Statutes and By-laws and other administrative and financial procedures were prepared to make way for a new Association. By action of the IUGG Council on 4 July 2007, the new Association was welcomed into the IUGG family.

After the General Assembly in Birmingham, UK (1999), election procedures for IUGG officers were modified to allow additional nominations following the report of the Nominating Committee. At the General Assembly in Perugia, Italy (2007), the duties of the Bureau, the Secretary General and the Treasurer with regard to the administration were refined, and Statute 27 was modified so that while French and English are the official languages of the Union, the English version of the Statutes is now the definitive version of the text. The membership and duties of the Finance Committee were addressed at the 2003 and 2011 General Assemblies, and at the General Assembly in Melbourne, Australia (2011), IUGG Honorary membership (Fellows) was instituted to honor individuals for their exceptional contribution to Earth and space sciences or international cooperation in geodesy or geophysics.

At the General Assembly in Prague, Czech Republic (2015), the composition of National Committees was clarified in order to advance the participatory culture of the Union and improve transparency. Also in Prague, it was decided that delegates to the IUGG Council should be appointed by the Adhering Bodies of Member Countries for the period between General Assemblies (normally for 4 years) so that the Council could vote electronically and make decisions between General Assemblies. This provision permitted the IUGG Bureau to propose several changes to the Statutes and By-laws following the Prague General Assembly. After consultations with the IUGG Council, the changes were approved unanimously on 5 April 2018 by electronic ballot.
The position of Vice President was replaced by Presidentelect, who then becomes President of the Union in the following term of office. The number of members of the Finance Committee was reduced from four to three people and the terms of office of the Secretary General, Treasurer, Bureau Members at large and Finance Committee members were redefined. The vote of the immediate Past President at the Executive Committee was restored.

\section{IUGG membership and finance}

The IUGG Council has approved a number of changes regarding membership since 1999. At the General Assembly in Birmingham, UK in 1999, the category of Associate Membership (characterized by exemption from paying annual dues) was created; Associate members were not allowed to sit in Council meetings (as opposed to members with Observer status, who could attend Council meetings but not vote). A By-law change clarified that scientists from all countries could attend scientific meetings of the Union and of the Associations and participate as observers in Commissions of the Union and in the Associations. At the General Assembly in Sapporo, Japan (2003), it was decided that one delegate from each Associate member country could attend Council meetings as listeners only. It was also agreed that other "Listeners" could attend Council meetings with the permission of the President, although a vote of Council members could exclude Listeners if appropriate. At the General Assembly in Perugia, Italy (2007), the number of financial categories to determine membership dues was increased to 14. At the General Assembly in Melbourne, Australia (2011), Affiliate membership was added to provide a mechanism to formalize linkages with various international and regional organizations dealing with Earth and space sciences, and the Statutes and By-laws were clarified with regard to Associate and Observer membership status. At the General Assembly in Prague, Czech Republic (2015), a change was made to allow a representative of an Associate Member to speak (without the right to vote) at Council meetings, and individuals from countries in Associate or Observer status or from nonMember countries could be elected to Association office (except for the position of the Association President because the Association President is a member of the IUGG Executive Committee).

As of 1 January 2019, IUGG had 72 National Members (see Appendix A for the IUGG Members since 1919, and Table 2 for the changes in the number of members for the last 20 years). The paying members are placed in categories from 1 to 14 depending on their financial contribution to the Union (the membership dues rise with increasing category number). At present, the highest category used is category 11. The members pay dues according to a number of units assigned to their category (in category 1 the number of units is 1 , and in category 11 the number is 35 ). According to 
Table 2. IUGG General Assemblies (GA) from 1999 to 2019, and IUGG Presidents and Secretaries General elected.

\begin{tabular}{|c|c|c|c|c|c|c|}
\hline No. GA & Year & Place & No. of attendees & $\begin{array}{r}\text { No. of Member } \\
\text { countries }\end{array}$ & President & $\begin{array}{l}\text { Secretary } \\
\text { General }\end{array}$ \\
\hline XXIII & 2003 & Sapporo, Japan & 4151 & 65 & $\begin{array}{l}\text { Uri Shamir } \\
\text { (Israel, 2003-2007) }\end{array}$ & $\begin{array}{l}\text { Jo Ann Joselyn } \\
\text { (USA, 1999-2007) }\end{array}$ \\
\hline XXIV & 2007 & Perugia, Italy & 4375 & 66 & $\begin{array}{l}\text { Tom Beer } \\
\text { (Australia, 2007-2011) }\end{array}$ & \multirow{3}{*}{$\begin{array}{l}\text { Alik Ismail-Zadeh } \\
\text { (Germany/Russia, 2007-2019) }\end{array}$} \\
\hline XXV & 2011 & Melbourne, Australia & 3392 & 70 & $\begin{array}{l}\text { Harsh Gupta } \\
\text { (India, 2011-2015) }\end{array}$ & \\
\hline XXVI & 2015 & Prague, Czech Rep. & 4231 & 71 & $\begin{array}{l}\text { Michael Sideris } \\
\text { (Canada, 2015-2019) }\end{array}$ & \\
\hline XXVII & 2019 & Montreal, Canada & & 72 & & \\
\hline
\end{tabular}

a decision made at the XXII IUGG General Assembly in Boulder, USA (1995), the price of 1 unit is determined every year using an inflator index obtained from the Bureau of Labor Statistics, U.S. Department of Labor. The funds received as dues are the basis for IUGG's operations as a scientific union, although Union Associations may have their own funds earned through donations, book sales, or other fundraising efforts. The funds are spent to support scientific activities of Union Associations and Commissions; international scientific programs, projects and services; general and scientific assemblies and other meetings; the IUGG Grants and Geoscience Education programs; the International Lithosphere Program; the International Science Council; travel of students, early career scientists, and scientists from developing countries to attend scientific meetings; and administration and management.

\section{The IUGG Secretariat}

The IUGG Secretariat has undergone significant changes to allow for modern governance, especially making use of the World Wide Web and digital technologies. The Union has had a web site since 1999 maintained by a web-master located in France (1999-2000, 2005-2007), USA (20002005), and Russia (since 2007), and overseen by the IUGG Secretary General. The IUGG Yearbook was first published electronically in 2004. Annual reports since 2001 (and earlier as digital scans become available) are also posted online. Since November 2014, the Secretariat has used web-conferencing software to support real-time communications between IUGG Bureau and Executive Committee Members through text-based instant messages, voice and video chat, online presentations, web conferences, and desktop sharing. This technology increases communication and productivity, conserves time and reduces travel expenses, and accelerates the decision-making process. IUGG is on Twitter (https://twitter.com/theiugg, last access: 29 January 2019) and Facebook (https://www.facebook.com/
InternationalUnionGeodesyGeophysics, last access: 29 January 2019).

The IUGG Electronic Journal began monthly publication on 1 February 2001, as a means to communicate the actions of the Union and the Associations. A web-based IUGG Central Electronic Library (CEL) was established (2013) to stimulate the exchange of scientific knowledge by (i) archiving, (ii) presenting, and (iii) publishing IUGG-related documents; at present one single platform for all of this is under construction. IUGG-related documents include reports, yearbooks, ejournals, newsletters, conference abstracts, oral/poster presentations, and more, originating from IUGG and its Union Associations, Union Commissions, Committees, Liaisons, Research Programs, and Science Education Events. New digital IUGG-Association logos were professionally designed and approved by the Executive Committee in December 2016.

From mid-1999 to 2007 the office of the IUGG Secretary General was hosted by the University of Colorado at Boulder, USA, within the Cooperative Institute for Research in Environmental Sciences (CIRES). The IUGG Secretariat moved to Karlsruhe, Germany in 2007, where it was hosted by the Geophysical Institute at the Karlsruhe Institute of Technology (KIT; former Karlsruhe University). On 7 June 2013, at the invitation of Reinhard Hüttl, Scientific Executive Director of the GFZ German Research Centre for Geosciences (GFZ-Potsdam), the office of the IUGG Secretariat was relocated to Potsdam, Germany. Salary and facilities for an Executive Secretary (Assistant Secretary General) to support the Secretariat are provided by the GFZ-Potsdam. Additional financial support to the Secretariat comes from the German Research Foundation (DFG), which provides funds for the position of Assistant of the Executive Secretary and for business travel of the IUGG Secretary General.

The IUGG historical records were transferred in 2001 to the Niels Bohr Library of the Center for the History of Physics of the American Institute of Physics. The historical records consist of documents and correspondence dating 


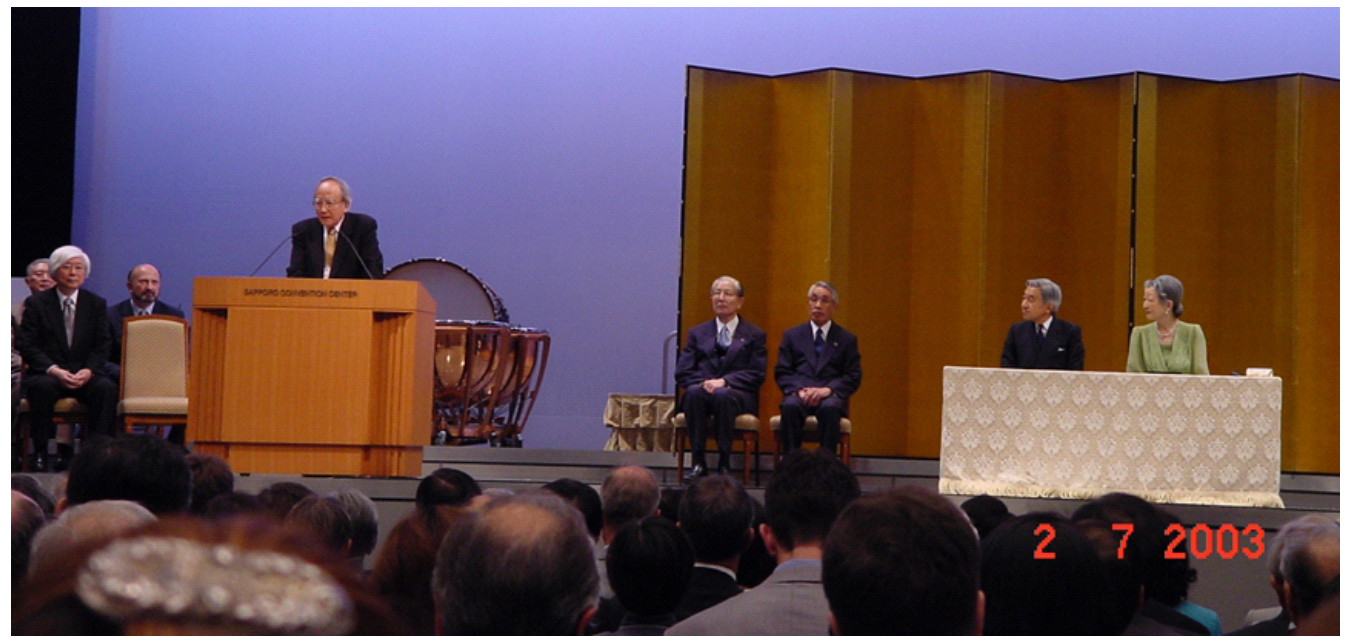

Figure 1. Opening ceremony of the XXIII IUGG General Assembly. Seiya Uyeda, Chair of the Local Organizing Committee (welcoming the Assembly's participants) on the left, and His Majesty The Emperor of Japan and The Empress of Japan on the right of the photo (courtesy: S. Uyeda).

from the origin of the Union in 1919, and extending into the mid-1990s; additional material was sent in December 2007 (AIP, 2019).

\section{Highlights of IUGG General Assemblies}

As the 21 st century began, the actions from the XXII General Assembly held in Birmingham, UK, in 1999 were in place. There was one change in the officers of the Bureau elected in Birmingham: L. Vere Shannon (South Africa) resigned, and by action of the Executive Committee, was replaced by Tom Beer (Australia).

\subsection{General Assembly (30 June-11 July 2003, Sapporo, Japan)}

IUGG President Masaru Kono (Japan) presided. Vice President was Uri Shamir (Israel), Secretary General was Jo Ann Joselyn (USA), Treasurer was Aksel W. Hansen (Denmark), and Bureau members were Junyong Chen (China), Harsh Gupta (India), and Tom Beer (Australia). This was the first IUGG General Assembly to be held in Asia. His Majesty The Emperor of Japan addressed the Opening Ceremony (Fig. 1). Seiya Uyeda chaired the Local Organizing Committee, and Atsuhiro Nishida chaired the Scientific Programme Committee. The theme of the General Assembly was "State of the Planet: Frontiers and Challenges", and featured four Union lectures and 182 scientific sessions including eight Union Symposia. The IUGG volume "The State of the Planet: Frontiers and Challenges in Geophysics" was published in the AGU Geophysical Monograph series (Sparks and Hawkesworth, 2004). Attendance was impacted by a serious global outbreak of the Sudden Acute Respira- tory Syndrome (SARS); some had to delay or cancel travel arrangements due to precautionary requirements.

Three special committees presented reports: IUGG Structure, Goals, and Objectives; IGY +50 , which began as a simple celebration but culminated in four major international programs as described earlier: eGY, IHY, IPY, and IYPE. A special Union Symposium "Geosciences - The Future" was presented by a working group of young scientists that was initiated by Vice President Uri Shamir, to stimulate involvement and leadership by early career scientists. A discussion of IUGG Structures, Goals, and Objectives centered on the responses to questionnaires that had been submitted to the IUGG Adhering bodies, National Committees, and Associations. An addition to Council business was an informal meeting of the delegates led by Ronald Stewart (Canada) during which delegates could freely express ideas and opinions.

During this quadrennium, IUGG allocated financial support for meeting attendance and inter-Association initiatives to benefit developing countries (22 meetings, workshops and schools in 17 different countries), as well as interdisciplinary and inter-Union initiatives that particularly benefited developing countries. ICSU also awarded grants to promote Association research objectives.

Resolutions (IUGG Archives, 2003) were adopted that supported geophysical seafloor observations, ocean modeling, a geodetic observing system, Earth monitoring with synthetic aperture radar, data access under the Comprehensive Nuclear-Test-Ban Treaty (CTBT), and the need for release of airborne and marine magnetic data. 


\subsection{General Assembly (2-13 July 2007, Perugia, Italy)}

IUGG President Uri Shamir (Israel) presided. Vice President was Tom Beer (Australia), Jo Ann Joselyn (USA) continued as Secretary General, Aksel W. Hansen (Denmark) as Treasurer, and Bureau members were Yun-tai Chen (China), Harsh Gupta (India), and Ali A. A. Tealeb (Egypt). Held in the historic Umbria Region of Italy, Lucio Ubertini chaired the Local Organizing Committee and Paola Malanotte-Rizzoli chaired the Scientific Program Committee. The theme was "Earth: Our Changing Planet", and the Assembly featured four Union lectures, thirteen Union symposia, and 187 Association and inter-Association symposia and workshops.

The International Association for Cryospheric Sciences (IACS) became the 8th IUGG Association (Fig. 2). A new document, Guidelines on IUGG Administration, was introduced. The 50th anniversary of the IGY was celebrated, and the eGY was inaugurated, joining the other IGY+50 scientific programs: IHY, IPY, and IYPE.

During the preceding 4 years, IUGG allocated funds to the organizers of 32 symposia, workshops, schools or meetings in 25 different countries, most of them developing countries. In addition, grants were allocated in the years 2004 and 2005 to support eight inter-Association initiatives that specifically benefited developing countries. By action of the 2005 Executive Committee, the grants were suspended for 2006-2007 in order to build a reserve that could be used to seed potential initiatives under Geosciences in Africa. This program, adopted by the GeoUnions, cooperated with the ICSU Regional Office in Africa and supported the eGY-Africa program to help to reduce the digital divide through better Internet access for scientists (and others) in universities and similar institutions in Africa. In addition, IUGG supported inter-Union activities, including ILP, WCRP, and the Federation of Astronomical and Geophysical Data Analysis Services (FAGS). IUGG received competitive grants from ICSU to promote IAGA and IAHS research objectives, nominated persons for numerous panels and working groups, and endorsed the ICSU "Agenda for Action" with regard to Science in the Information Society.

Resolutions (IUGG Archives, 2007) adopted included support of an International Astronomical Union's resolution on nomenclature and definition of TDB (Temps Dynamique Barycentrique); support of Geocentric and International Terrestrial Reference Systems (GTRS and ITRS) and the Global Geodetic Observing System (GGOS); eGY and Data Rescue; Ionosphere Satellites; The Urgency of Addressing Climate Change; Intensified Study of Aerosol Pollution Effects on Precipitation; and Reduction of Risk from Natural Hazards.

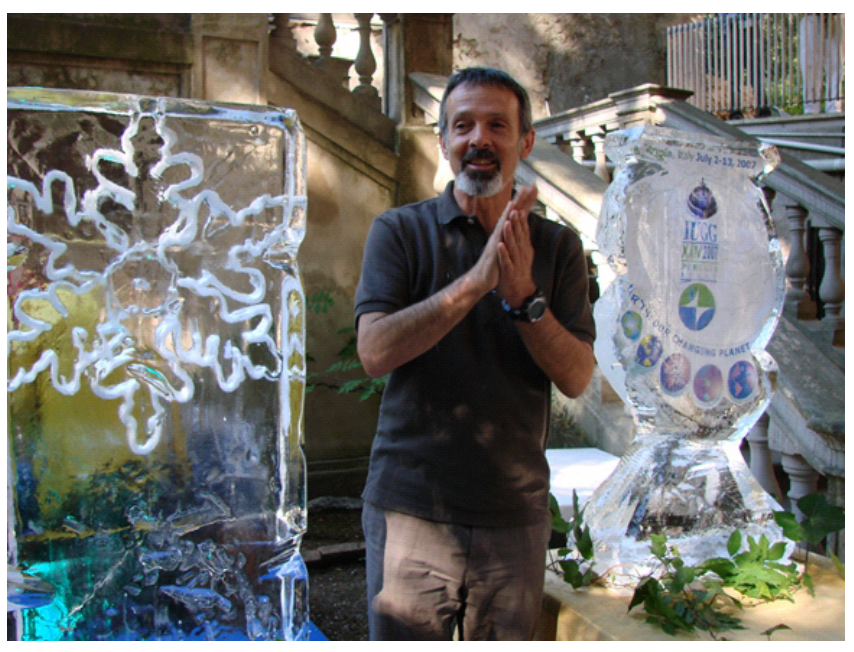

Figure 2. IUGG's congratulations on the occasion of the birth of IACS. Featured is Georg Kaser, the first IACS President (source: IUGG archives).

\subsection{General Assembly (27 June-8 July 2011 - Melbourne, Australia)}

IUGG President Tom Beer (Australia) presided. Vice President was Harsh Gupta (India), Secretary General was Alik Ismail-Zadeh (Germany/Russia), Aksel W. Hansen (Denmark) continued as Treasurer, and Bureau members were Yun-tai Chen (China), David Jackson (USA), and Ali A. A. Tealeb (Egypt). This was the second IUGG General Assembly to be held in Australia, and the third time it was held outside of Europe and North America. Ray Cas chaired the Joint Australia and New Zealand Organizing Committee and Peter Manins coordinated the Scientific Program Committee. The theme was "Earth on the Edge: Science for a Sustainable Planet", and the Assembly featured nine Union lectures and a total of 198 symposia and workshops.

The Royal Society (the UK Adhering Body to IUGG) developed a program to engage African scientists in the work of ICSU international unions, and paid for 3-year membership dues of the Democratic Republic of Congo, Ghana, and Morocco, IUGG Associate Members, allowing them to participate in full in Union's activities. IUGG co-sponsored and took an active part in the international programs dedicated to the 50th anniversary of the IGY. Association scientific assemblies were held in Reykjavík, Iceland (IAVCEI); in Cape Town, South Africa (IASPEI); MOCA, a joint assembly of IAMAS, IAPSO and IACS was held in Montreal, Canada; IAGA held its assembly in Sopron, Hungary; IAG met in Buenos Aires, Argentina; and IAHS held its assembly together with the International Association of Hydrogeologists in Hyderabad (India). The IUGG Union Commissions organized several conferences and symposia: two CMG conferences on mathematical geophysics in Longyearbyen (Norway), and in Pisa (Italy), two SEDI conferences 
in Kunming (China), and Berkeley (USA), and three GRC symposia in Barcelona (Spain), Oslo (Norway), and Torino (Italy). GRC took active part in the organization and running of the ICSU-sponsored ENHANS project events in Iguassu (Brazil), San Francisco (USA), Pretoria (South Africa), Antalya (Turkey), and Melbourne (Australia). A new Union Commission for Data and Information was set up to provide a focused and sustainable organizational structure that supports and strengthens IUGG science through integrated scientific information activities. Four new Union Committees on Capacity Building and Education, Honours and Recognition, Membership Issues, and Visioning were set up to increase IUGG visibility worldwide.

Seven multi- and inter-disciplinary international scientific projects were supported through the IUGG Grants Program. IUGG meeting support was allocated to the organizers of 43 symposia, workshops, schools or meetings in 31 different countries, most of them in developing countries. ICSU competitive grants were awarded to promote research on natural hazards and disaster risks as well as geophysical research and geoinformation in Africa. IUGG also supported inter-Union activities, including ILP, the WCRP, and FAGS, now transformed into the World Data System (WDS).

Resolutions (IUGG Archives, 2011) that were adopted included the issue of standardizing terminology for glacier mass balance measurements and for classification of snow on the ground; endorsement of the International Celestial Reference Frame; the need for gravity and magnetic field satellite missions; and adoption of the International Thermodynamic Equation of Seawater - 2010 (TEOS-10). It was noted that the IUGG Executive Committee had adopted several resolutions and statements during the inter-General Assemblies period with regard to several natural disasters (noted elsewhere).

\subsection{General Assembly (22 June-2 July 2015, Prague, Czech Republic)}

IUGG President Harsh Gupta (India) presided. Vice President was Michael Sideris (Canada), Secretary General was Alik Ismail-Zadeh (Germany/Russia), Aksel W. Hansen (Denmark) was Treasurer, and Bureau members were Isabelle Ansorge (South Africa), Pierre Hubert (France), and Kenji Satake (Japan). Prague was the only city to host the IUGG Assembly for the second time, having hosted the Third IUGG General Assembly in 1927. Vladimir Cermak chaired the Local Organizing Committee and Eduard Petrovsky chaired the Scientific Program Committee. The Theme of the General Assembly was "Earth and Environmental Sciences for Future Generations". There were nine Union lectures and 11 Union symposia; Nobel Prize winner Yuan Tseh Lee presented a Union lecture on "Transformation of human society for sustainable future." The scientific program included 198 symposia and workshops.
The Visioning Committee prepared, and the delegates approved, a draft Strategic Plan for 2016-2023 to be developed along with a plan for implementation (the final plan was approved by the Council by electronic ballot in 2016; the implementation actions were approved by the Bureau in 2017). A new category of Union Membership, Affiliate, was established to strengthen cooperation with geoscientific organizations worldwide. Since 2012, six scientific organizations became IUGG Affiliate Members: the Commission for the Geological Map of the World, the Young Earth Scientists Network, the American Geosciences Institute, the International Association for Mathematical Geosciences, the International Landslides Consortium, and the International Association for Geoethics.

The first IUGG awards were presented (Fig. 3). The full list of IUGG Early Career Scientist Awards, Elected Fellows who have made outstanding contributions to geodesy and geophysics, and Conferred Fellows honored for service as officers of IUGG and the Associations, is maintained on the IUGG website. The IUGG Gold Medal was awarded to Sir Brian J. Hoskins (UK) for "his scientific contributions that have been pioneering and profound in almost all aspects of the atmospheric and climatological sciences, with strong linkages to IUGG and its Associations."

An agreement was signed with Cambridge University Press to develop a new series of special publications of IUGG to publish peer-reviewed books on perspectives and reviews in multidisciplinary research. The first volume of this series, "Extreme Natural Hazards, Disaster Risks and Societal Implications", was published in 2014 (Ismail-Zadeh et al., 2014), the second volume, "Dynamics and Predictability of Large-Scale, High-Impact Weather and Climate Events", in 2016 (Li et al., 2016), and the third volume, "Global Change and Future Earth", in 2018 (Beer and Alverson, 2018). IUGG established a new Science Education Program to enhance geophysical and geodetic science education. In 2012-2015, IUGG funded 24 advanced schools and workshops at the Abdus Salam International Centre for Theoretical Physics (ICTP) in Trieste, Italy. ICSU grants promoted geophysical research in Africa and funds to network the magnetic community in the northern Indian Ocean region. Also, nine interdisciplinary international scientific projects were supported through the IUGG Grants Program.

In 2013 IAVCEI proposed to open membership of IUGG to individual scientists at the same time as the IUGG Executive Committee was discussing various possibilities for individual Union membership. Based on the majority of the opinions from Union Associations and National Members, the IUGG Executive Committee agreed that the Union should continue with National, Affiliate, and Honorary Memberships, and each Union Association may introduce individual membership programs to allow active scientists from non-Member countries to participate in activities of Associations. Association scientific assemblies were held on several continents in 2013: the joint Scientific Assembly DACA- 


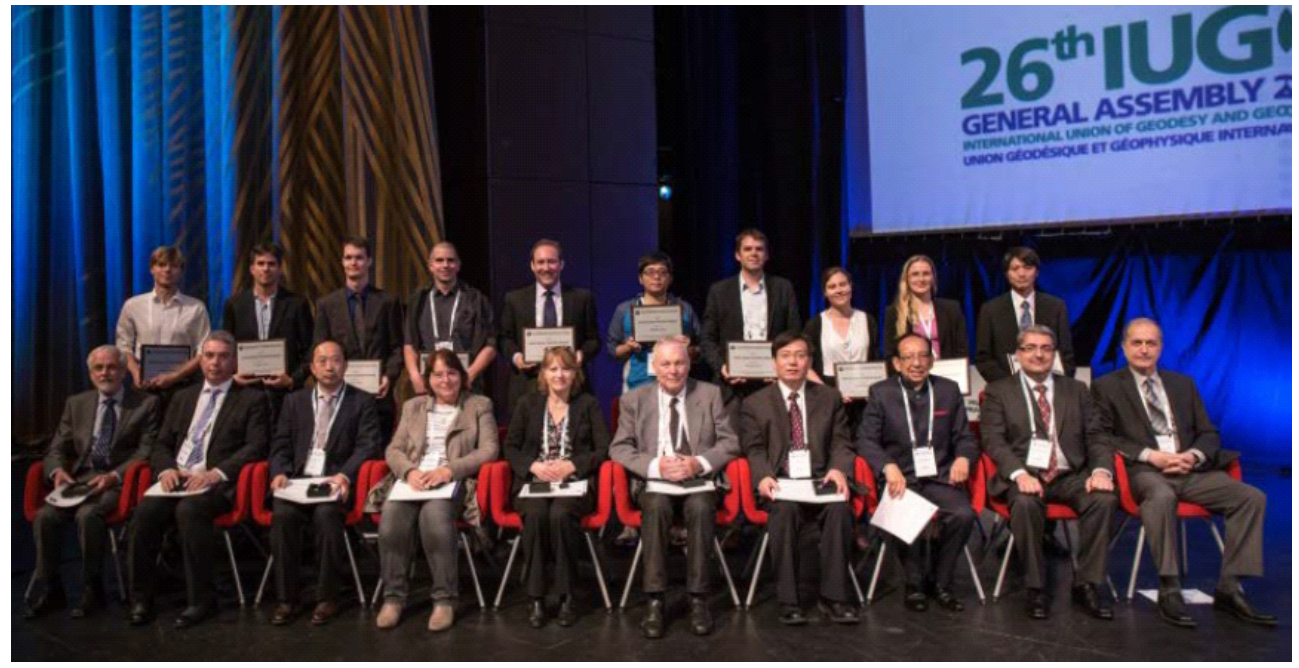

Figure 3. Award ceremony at the XXVI IUGG General Assembly, Prague, Czech Republic, 2015.

13 of cryospheric (IACS) and atmospheric (IAMAS) scientists in Davos, Switzerland; the IAGA Scientific Assembly in Merida, Mexico; the joint Scientific Assembly of hydrologists (IAHS), oceanographers (IAPSO) and seismologists (IASPEI) "Knowledge for the Future" in Gothenburg, Sweden; the IAVCEI Scientific Assembly in Kagoshima, Japan; and the IAG Scientific Assembly in Potsdam (Germany) celebrating the 150th anniversary of the association. The IUGG Union Commissions organized seven scientific events in Asia, Europe, and North America. The Union cosponsored 43 international scientific events.

Resolutions (IUGG Archives, 2015) that were adopted included the Role of Ocean in Climate, Future Satellite Gravity and Magnetic Mission Constellations, the Global Geodetic Reference Frame, Real-time GNSS (Global Navigation Satellite System) Augmentation of the Tsunami Early Warning System, and cooperation in Geo-energy Resources and International Scientific Activities.

The members of the Bureau for the ensuing quadrennial were elected: President Michael Sideris (Canada); Vice President Kathryn Whaler (UK); Secretary General Alik IsmailZadeh (Russia/Germany); Treasurer Aksel W. Hansen (Denmark); Bureau Members: Isabelle Ansorge (South Africa), Pierre Hubert (France) and Chris Rizos (Australia). A vote of the delegates selected Montreal, Canada, as the venue of the XXVII IUGG General Assembly (8-18 July 2019).

\section{IUGG tomorrow}

IUGG is entering its second century. A healthy future for the Union requires emphasis on basic Earth and space sciences as well as science for society. The landscape of Earth and space sciences is changing: we are witnesses of pressing challenges, such as sprawling towns and the growth of megacities, climatic and environmental change; ocean acidification and sea pollution; disasters due to natural and human-induced hazards and associated losses due to vulnerability of societies; unsustainable land use; food insecurity; and depletion and scarcity of mineral resources and water. The importance of scientific understanding of the urgent problems of society has never been greater, as humanity engages in the problems of living sustainably on planet Earth. Governments, funding agencies, international and national organizations, professional societies and international unions are dedicating more attention to the aspects of research related to the environment, renewable natural resources, clean water, disaster reduction, resilience and others. To address these challenges, the scientific community decided in 2017 to form a new council, the International Science Council (ISC), merging ICSU and ISSC, to create a unified, global voice of science with a powerful presence in all regions of the world and representation across the natural and social sciences. As a founding member of ISC, the Union has a responsibility to ensure that its activities align with the ISC's agenda.

\subsection{Basic research}

Geoscientists need to continue to put their basic results to use, and inter- and trans-disciplinary (ITD) approaches are vital to making progress in science for society. The coupling between the spheres of the Earth and space sciences as well as between those and social sciences is often lost. Integrated research combining expertise from relevant disciplines will help quantify the observed processes and, more importantly, elucidate which interactions between spheres are essential. According to Adams (2013), the best science results from international collaboration, and hence IUGG should think about new ways and incentives to enable more scientists to participate in international networks. This need for increased collaboration is set against changes in the current science 
landscape and sociopolitical environment that make international cooperation more difficult. Given these realities, IUGG will have to work especially diligently to adapt to this new environment and promote cooperation.

\subsection{Data issues}

The Internet and advances in technology have been enhancing the ability of scientists to collect, archive, and distribute data across all fields and nations. Strengthening norms around openly accessible research and broadening global access to data, digital technologies, and reliable internet connections would be a boon would be a boon to scientists in developing countries and to independent/unaffiliated scholars everywhere, enabling them to further advance their own research thanks to prompt and equal access to advanced datasets and model results. In order to make the promises of the digital age a reality, existing geodetic and geophysical data centers and data services should be expanded, and new multi-disciplinary data centers and data services should be established to enable scientists to work in interdisciplinary areas with unrestricted access to data for scientific research. Also, such centers could make data produced with public participation (sometimes called "citizen science" data) more valuable, e.g., ash samples collected after the 2010 eruptions of Eyjafjallajökull in Iceland or felt earthquake information.

A significant challenge facing geosciences is to combine "big data" (that is, the large volume, high velocity and/or variety data assets that demand modern forms of processing enabling deep insight and decision making) with state-ofthe-art models for better understanding of nature's complex systems. This will be a key component of progress in geosciences in the near future. IUGG, via its permanent geodetic and geophysical services, should continue to promote the development of existing and new sophisticated, cuttingedge methodologies and tools in data collection, transmission, analysis, and dissemination of outputs to help address challenging problems in Earth and space sciences. IUGG's role in promoting an open data policy as well as the activities of observational and data services and in encouraging international investment in observing systems is, and will continue to be, important. We envisage that IUGG will enhance its working relationship with such bodies as the intergovernmental Group on Earth Observations (GEO), CODATA and WDS to promote data curation and openness and data analysis for new discoveries. Knowledge transfer can be accomplished successfully by utilizing mass media outlets as well as by traditional ways of cooperation with policymakers. The web and social media are the best ways to reach the youth audience, a key demographic in ensuring the future of geoscientific research, as well as a broader audience more generally, including communities that may not have had much access to advanced scientific findings in the past (e.g, communities lacking financial or scholarly resources).

\subsection{Interdisciplinarity}

Societal problems need an integrated, trans-disciplinary scientific approach (e.g., Ismail-Zadeh et al., 2017). The way forward for IUGG and other scientific unions and professional societies is to foster fundamental science for new discoveries and promote co-designed/co-productive ITD research. IUGG should place an emphasis on scientific investigations for interventions, that is, foster action-oriented solutions of societal problems. For example, for disasters caused by natural hazard events, relevant research can be integrated and co-produced. A way of integration and coproduction could be through the maturation of disaster science and through trans-disciplinary approaches aiming at indepth investigations using systems analysis approaches. Systems analysis allows a disaster and/or disaster risk problem to be decomposed into its component parts to study how well they work, interact, and contribute to the overall aim of risk reduction. The final goal of the ITD approach is to issue recommendations for actions to reduce risks and to improve societal resilience (Cutter et al., 2015). Hence, IUGG should promote both disciplinary and ITD approaches in science education. Training and education within geoscience as well as practice domains can, through co-engaged and co-produced knowledge, enhance our understanding of the needs of vulnerable regions and populations, and enable practitioners and policymakers to use it to better effect.

One of the needs for co-productive research is to evaluate the quality and the success of ITD studies (NAS, 2004). IUGG has a role to play in such assessments. Together with other international scientific bodies, IUGG can lead in proposing and developing norms for ITD practice and geoscience education. For example, IUGG might develop appropriate standards and relevant skills to be mastered by students and scientists who participate in ITD education and research. The Union, via National Committees, could lobby national funding agencies to support ITD research projects and promote success stories of international ITD findings.

\subsection{Future of international scientific organizations}

Looking into the future, one may ask: does modern science need international non-governmental organizations? Can the national and regional organizations replace them? What would happen if international scientific unions disappear? Historically, IUGG and other international scientific unions were set up as a response to the need for cooperation between nations, as many aspects of geosciences required international collaboration. Neither national nor regional professional societies (e.g., the American Geophysical Union (AGU), the Asia Oceanic Geosciences Society (AOGS) or the European Geosciences Union (EGU)) can truly replace international unions, as national and regional societies' major concern is typically their own nation or geographical region. Three possible scenarios could be drawn up for fu- 
ture development of IUGG and other international unions (Ismail-Zadeh, 2016): (1) integration of international geoscientific unions (e.g., GeoUnions of the ISC) and professional societies of geoscientists (e.g., AGU, AOGS, EGU); (2) reshaping of scientific priorities and structures of current geoscience organizations and their independent development in a cooperative way; and (3) competition between international, regional and national unions and societies.

The first scenario could possibly lead to the development of an international geosciences union with major regional branches in Africa, central and South America, Asia/Oceania, and North America/Europe, and with major disciplinary and interdisciplinary associations. After convergence, integration, and finally fusion of international geoscientific unions, on the one hand, and convergence or alliance of national and regional geoscience societies, on the other hand, the international geosciences union could then act as a (financially self-maintained) scientific body, coordinating activities of its regional branches and its scientific associations. This union could provide a full spectrum of services and benefits to its members: from scientific meetings and publications to involvement in the initiation, promotion, and implementation of national, regional and international scientific programs, scientific specialized commissions and working groups, and geoscientific services and outreach programs linking science to society and national and international policy. Such an international organization could become a single but powerful voice of Earth and space sciences and promote science to benefit humanity in a more efficient way.

The second scenario is more conservative. International scientific unions as well as national and regional societies of geoscientists would continue their operations reshaping their structure and activities to meet modern scientific challenges. They could establish/strengthen cooperation amongst themselves using a complementary rather than competitive approach. In the long term, this scenario may lead to a fusion (such as in the first scenario).

The third scenario would have a negative impact on international cooperation and development. National and regional societies of geoscientists would continue to enhance their activities and to attract more and more scientists (especially those of younger generations) to membership and to address national and regional policies encouraged by national governments or regional political structures (e.g., the European Union). National scientific institutions or academies provide the funds necessary for adherence to the international Unions. If these bodies in some developed countries were to adopt shortsighted policies by withdrawing from membership of the Unions or reducing the amount of membership dues paid, the international Unions would lose the ability to continue their operations and would cease to exist. The disappearance of international scientific unions would (i) lead to "nationalism" in science (e.g., US, European or Chinese science), which may lead to replacement of "science for peace" by "science for defense", and to significant polar- ization; (ii) result in the disintegration of many important scientific programs already established; (iii) harm (if not end) new international multidisciplinary programs; and (iv) become a destructive force for the world's scientific development and cooperation, as many developing nations get involved in scientific programs mostly via international programs and through the activities of international scientific unions. Also, climatic and environmental change influences the world globally, and disasters caused by natural hazard events do not respect political borders. We need globally collected and shared data and joint research cooperation efforts to understand, model and forecast these and many other phenomena and their societal impacts. Our global networks of sensors and observatories, remote sensing missions, and international marine cruises to collect data over the oceans, are crucial. Science with borders does not serve anyone well.

These scenarios describe a wide range of possibilities for the future development of IUGG and other international scientific unions, and being extreme case scenarios the first and third scenarios are unlikely to be realized in full.

\subsection{Scientific challenges}

IUGG will continue to provide balanced, factual, and independent scientific information within its remit of Earth and space sciences. Besides knowledge, which satisfies the curiosity of human beings related to the planet on which they live, and to the Moon, planets, Sun, and stars, which they observe every day, IUGG provides information, understanding, and guidelines on important society-relevant problems to deliver science for the benefit of humanity. Among the problems IUGG has been addressing and will continue to address are: (i) climate variability and the contribution of $\mathrm{CO}_{2}$ emission to its change to ensure continued habitability of our planet for future generations; (ii) environmental pollution and its reduction in megacities to improve the quality of life; (iii) natural hazards (e.g., hurricanes, floods, earthquakes, landslides) and mitigation/prevention of disasters to save lives and infrastructure; (iv) weather, water, and soil conditions to assist farmers to grow food and provide other indispensable ecosystem services; (v) mineral resources for future generations; (vi) clean water and reduction in contamination to preserve and enhance human and ecosystem health; (vii) space and geodetic measurements for navigation of airplanes and satellites and other applications; and (viii) pollution of oceans and seas, biodiversity and food security. IUGG will continue to increase geoscience literacy through capacity building activities globally and especially in the developing world.

One of current challenges of scientific organizations, including IUGG, is to promote and to strengthen research cooperation fostering development for science policy within a complicated scientific landscape with emerging policyoriented international programs. Science policy and diplomacy have been always essential components of IUGG activ- 
ities and should remain in its core activities. Recent examples of science policy and diplomacy work include a synthesis report on science for disaster risk reduction presented at the UN Third World Conference on Disaster Risk Reduction in 2015 (Ismail-Zadeh and Cutter, 2015), a report on future of the ocean submitted to the G7 Science Ministers meeting in 2016 (Williamson et al., 2016), and publications on global change and the future of our planet (Beer et al., 2018), and disaster-related science diplomacy (Kontar et al., 2018).

Adopted by the UN General Assembly in 2015, the 2030 Agenda for Sustainable Development represents a new way of thinking about how better to link issues such as climate change, natural disasters and education. It intertwines social, economic, and environmental targets in 17 Sustainable Development Goals (SDGs; UN, 2015). IUGG has been contributing, and will continue to do so, to many of the SDGs; in particular, IUGG deals with promotion of studies in air pollution (sub-goal 3.9), climate and environmental issues (1.5, 2.5, 3.9, 11.6, and 13.3), hazard and disaster risk $(1.5,2.5$, $11.5,11 \mathrm{~b}, 13.1$, and 15.3), education and capacity building (4.7, and 4b), energy (7a), oceans and seas (14.1-14.3, 14a, and $14 \mathrm{c})$, research and innovation $(9.5$, and $9 \mathrm{~b})$, water issues $(3.9,6.3-6.7,15.1$, and 15.3), and the Union continually seeks to improve it gender balance (5.5). All Union Associations, the Union Commissions such as GRC, CCEC, and UCDI, and the IUGG Committee on Capacity Building and Education will contribute to the SDGs mentioned above. For example, the IAMAS Commission on Atmospheric Chemistry and Global Pollution and the IAHS International Commission on Water Quality contribute to sub-goal 3.9 "to reduce the number of deaths and illnesses from [...] air, water [...] pollution and contamination"; the IASPEI-IAVCEIIAPSO's International Heat Flow and Tsunami Commissions advance knowledge on geothermal energy and tsunami, respectively; and IAPSO and IAHS contribute to issues of the ocean, seas and water (Ismail-Zadeh, 2016).

In 2016, IUGG issued its first Strategic Plan (IUGG-SP, 2016) and its implementation actions until 2023 (IUGG-IA, 2017). Among the important future key actions are to (i) promote IUGG to its constituents, and to geoscientists, policymakers and society in general; (ii) encourage closer cooperation between the IUGG groups and more effective engagement with sister organizations, and other partner agencies; (iii) assist underrepresented geoscientists to more fully participate in international science activities; (iv) strengthen the effectiveness of the Union's Council and the Executive Committee; (v) strengthen the promotion of fundamental research and education in the geosciences; and (vi) encourage more countries to become a member of the Union.

IUGG will maintain and enhance the links between scientists by initiating and developing various scientific, educational and outreach programs and scientific meetings, including the Union general assemblies and Association scientific assemblies, in cooperation with other international and intergovernmental organizations. It will continue to help in setting international geoscientific agendas, policies, recommendations, and guidelines.

IUGG played a significant role in the promotion of Earth and space sciences via international cooperation in the 20th century (the International Geophysical Year is a shining example of such cooperation). And the Union still has the potential to do so in the 21 st century by playing an important role in Earth and space sciences, particularly in establishing the terms and conditions for international research cooperation, setting scientific standards and nomenclatures, preparing universal tools, and supporting and promoting excellence, innovation, scientific freedom, inclusivity, diversity, and free access to geophysical data/services and to science education.

\section{IUGG leadership}

Finally, in this section we highlight the Presidents and Secretaries General, who have contributed significantly to the development of the Union and its Associations at the beginning of the 21 st century.

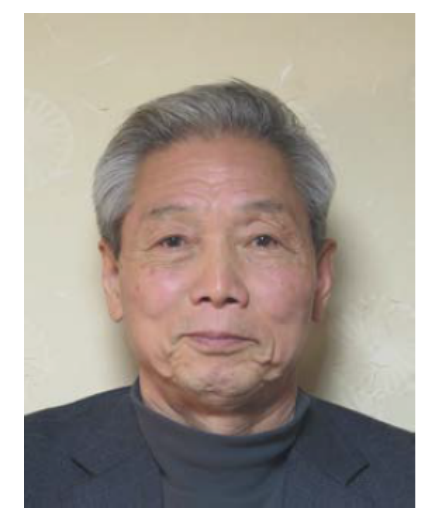

Masaru Kono, President (1999-2003). Masaru Kono (Japan, born in 1939) is a geophysicist, and his research is concerned with the magnetic field of the Earth, in particular, paleomagnetism and dynamo theory. Kono graduated from the University of Tokyo in 1963 and received his PhD from the same university in 1971. From 1968, he worked as Research Associate and then as Associate Professor at the Geophysical Institute of the University of Tokyo. Since 1980, he has held professor's positions at Tokyo Institute of Technology, the University of Tokyo, and Okayama University, until his retirement in 2005. Kono was IAGA Vice President (1991-1995), and then President (1995-1999). He also served as Vice Chair of the IUGG SEDI, as a Member of the Scientific Boards for the International Geoscience Program of UNESCO and IUGS, for the Science Council of Japan, and for the International Ocean Drilling Program. He is Fellow of IUGG, AGU, Japan Geoscience Union, IAGA, and honorary Fellow of the Royal Astronomical Society. 


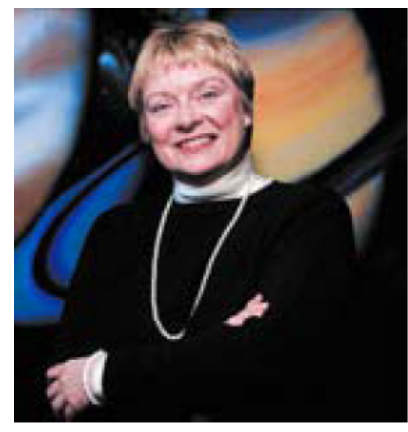

JoAnn Joselyn, Secretary General (1999-2007). JoAnn Joselyn (USA, born in 1943) is an astrogeophysicist who grew up during a period of, and achieved, amazing firsts, when advances in science and space exploration captured the imagination of people around the world. Following an undergraduate degree in applied mathematics at the University of Colorado (CU) at Boulder, she became the first woman to earn a doctoral degree at $\mathrm{CU}$ in astrogeophysics, the study of solar-planetary interactions. As a space scientist at the National Oceanic and Atmospheric Administration in Boulder, she showed that ejections of solar wind associated with disappearing solar filaments caused magnetic storms that can disrupt communications, electrical power transmission, space flight, and other emerging technologies. Joselyn became the first woman to be elected IAGA Secretary General (1995), and then the first woman and first American to be elected IUGG Secretary General. She is an IUGG Fellow.

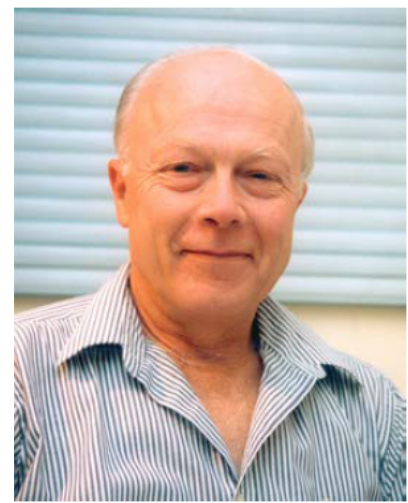

Uri Shamir, President (2003-2007). Uri Shamir (Israel, born in 1936) is a hydrologist. He graduated from the Technion - Israel Institute of Technology in 1962, and received his PhD in 1966 from the Massachusetts Institute of Technology, Cambridge, USA. Since 1979, Shamir has been Professor (Emeritus from 2004) in the Faculty of Civil and Environmental Engineering, and Founding Director (1992-2003) of the Stephen and Nancy Grand Water Research Institute, at the Technion. In 1992 Shamir has been Visiting Professor in various universities and research institutes in the USA and Canada, and was Chairman of the Israeli Association of Hydrology. He served as IAHS President (1991-1995), IUGG Vice President (1995-2003), and a Member of the ICSU Executive Board (2005-2011). He chaired the Technical Advisory Committee of the World Water Assessment Programme (WWAP-TAC), the UN water program led by UNESCO. He is a Fellow of IUGG, AGU, and the American Society of Civil Engineers, and a Foreign Member of the Spanish Academy of Science.

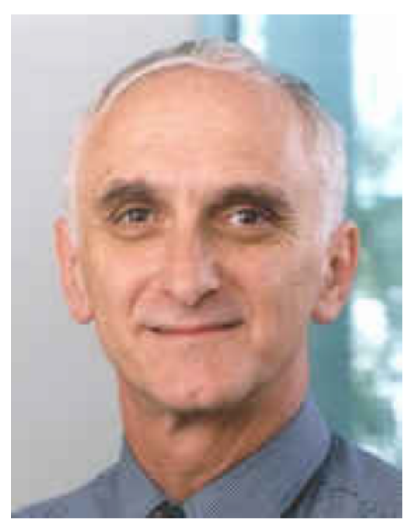

Tom Beer, President (2007-2011). Tom Beer (Australia, born in 1947) is an atmospheric scientist. Beer graduated from the University of Sydney in 1966, and obtained his $\mathrm{PhD}$ from the University of Western Ontario in 1971. He led the Climate Research Program of the Centre for Australian Weather and Climate Research, a partnership between the Commonwealth Scientific and Industrial Research Organization (CSIRO) and the Australian Bureau of Meteorology. Beer served IUGG as Bureau Member and Vice President before he was elected President. Beer was a founder of the IUGG GRC in 2000, becoming its first Chair, and of the IUGG CCEC in 2011, also becoming its first Chair. He served on the ICSU Committee for Scientific Planning and Review. He was awarded a Doctor of Science degree by the University of Canterbury in New Zealand. He was elected Fellow of several societies and foreign member of the Hungarian Academy of Sciences. 


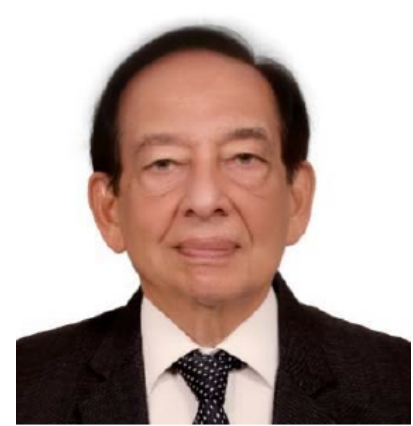

Harsh Gupta, President (2011-2015). Harsh Gupta (India, born in 1942) is a geoscientist and seismologist. He received his BSc (Hons) and MSc degrees from the Indian School of Mines, Dhanbad, before he obtained his $\mathrm{PhD}$ degree from the Indian Institute of Technology, Roorkee. He worked at the University of Texas at Dallas (USA) before he returned to India and became Director of the Centre for Earth Science Studies, Thiruvananthapuram, in 1982. He held positions of Vice Chancellor of Cochin University of Science and Technology, Director of the National Geophysical Research Institute (NGRI) in Hyderabad, and Secretary at the Department of Ocean Development of the Government of India. At present, Gupta is a Raja Ramanna Fellow at NGRI. Before Gupta was elected IUGG President, he served the IUGG Bureau as Member (1999-2007) and Vice President (20072011). He served on the ICSU Committee for Scientific Planning and Review. Gupta held leadership roles in several national and international scientific organizations. He is an AGU Fellow and a member of several national academies.

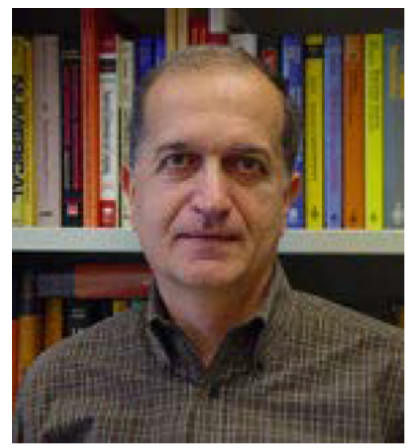

Michael Sideris, President (2015-2019). Michael Sideris (Canada, born in 1958 in Greece) is a geodesist with expertise in the fields of satellite Earth observation. He received his Diploma (Hons) from the National Technical University of Athens, Greece, in 1981, and M.Sc. (1984) and PhD (1987) from the University of Calgary, Canada. Since 1988 Sideris been working in the Department of Geomatics Engineering at the University of Calgary, where he is currently Professor and Associate Head (Graduate Studies). He has also served the university as Associate Dean of the Faculty of Gradu- ate Studies and Associate Dean of Research of the Schulich School of Engineering. He has been visiting Professor at several Asian, Australian, European, and South American universities/institutes. He was IAG Vice President (20032007) and President (2007-2011), and IUGG Vice President (2011-2015). Since 2016 Sideris has been serving on the GEO Program Board. He is an Alexander von Humboldt International Research Fellow, IAG Fellow, and IAG Honorary President.

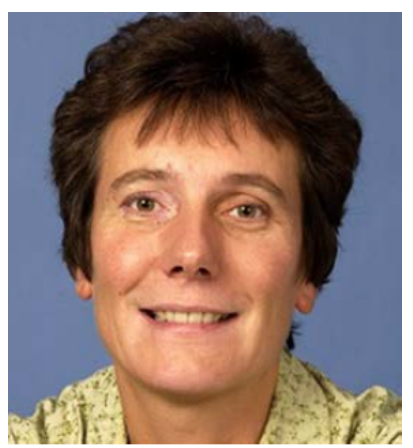

Kathryn Whaler, Vice President (2015-2019). Kathryn Whaler (UK, born in 1956) is a geophysicist with expertise in the fields of core dynamics, crustal magnetization, magnetotellurics, and geomagnetic observations. She received a BSc in Mathematical Physics from the University of Sussex in 1977 and a $\mathrm{PhD}$ from the University of Cambridge in 1981. Whaler joined the University of Leeds in 1983 as a lecturer, and in 1994, she moved to the University of Edinburgh to take up the Chair of Geophysics. She was the President of the Royal Astronomical Society (2004-2006). She served IAGA as Executive Committee Member (2003-2007), Vice President (2007-2011), and President (2011-2015) before she was elected IUGG Vice President (2015-2019). She has visited the NASA's Goddard Space Flight Center, Harvard University, the University of California at San Diego (as Green Scholar), Victoria University of Wellington, and Göttingen University (as Gauss Professor). Whaler is Fellow of AGU, the Institute of Physics, and the Royal Society of Edinburgh. 


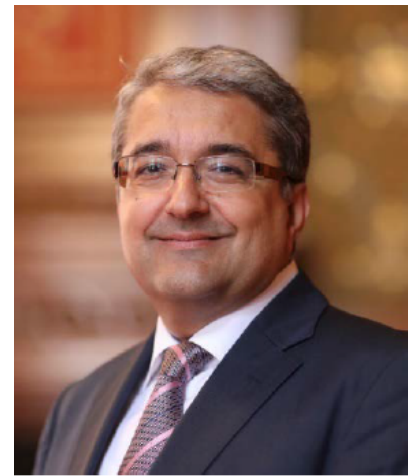

Alik Ismail-Zadeh, Secretary General (2007-2019). Alik Ismail-Zadeh (Germany/Russia, born 1961 in Azerbaijan) is a mathematical geophysicist, graduating from Baku State University (mathematics) and Lomonosov Moscow State University (physics) before being awarded $\mathrm{PhD}$ and DSc degrees in geophysics from the Russian Academy of Sciences (RAS). He has been Chief Scientist/Research Professor of RAS in Moscow since 1998, and Senior Scientist at the Karlsruhe Institute of Technology, Germany since 2001. He was a visiting professor at several universities, including in China, France, Japan, Sweden, UK, and USA. He is a co-founder of the IUGG GRC (Chair, 2004-2007) and a co-founder of the AGU Natural Hazard Section (Chair, 2009-2012). He has served or is serving on governing or advisory committees of international and intergovernmental organizations and programs, including AGU, CTBTO, UNISDR, and UNESCO. He was elected the first ISC Secretary (2018-2021). He is an elected member of Academia Europaea and an honorary Fellow of the Royal Astronomical Society.

\section{Conclusions}

Since its formation in 1919, IUGG has been committed to dedicated to initiating, promoting and coordinating international scientific studies and observations of the Earth and its environment in space. Today, as a vibrant modern scientific union of nations and individual scientists from all over the world, the Union is proud to promote research, science education, and capacity building via international cooperation, linking scientific knowledge to societal needs, and working toward a sustainable Earth (Ismail-Zadeh, 2016).

IUGG's centennial history (Appendix B) illustrates how hundreds of thousands of Earth and space scientists have developed and cooperated in international research to benefit society and promoted fundamental science as well as science for society. The Union encourages the application of this knowledge to societal needs, such as the mitigation of impacts from natural hazard events, the sustainable use of energy and mineral resources, and environmental preservation (Ismail-Zadeh and Beer, 2009). Particularly, IUGG responded vigorously to the challenges associated with climatic and environmental changes, disasters, water issues and many others, promoting research and scientific coop- eration. The Union has played an important regulatory role in geodetic and geophysical sciences, particularly in establishing the terms and conditions for international research cooperation, setting scientific standards and nomenclatures, preparing universal tools and data products, among other aspects. IUGG brought state-of-the-art science to less affluent countries through capacity building and science education. The Union links scientists via its scientific, educational and outreach programs to programs of intergovernmental organizations and assists in establishing international scientific agendas, policies, recommendations, and guidelines (IsmailZadeh, 2016).

Since the beginning of the 21 st century, IUGG has been involved in the process of reshaping its structure and activities to meet its scientific and organizational needs (see IsmailZadeh, 2016, for more details). The most notable of these changes are the following.

- To make the Union more vibrant in terms of decision making, the Council has become a continuously operating body.

- Scientists from any country are now eligible to hold most positions within the IUGG family with a few exceptions, which can only be held by scientists from Member Countries.

- Four standing Union Committees on Membership Issues, Capacity Building and Education, Honor and Recognition, and Visioning have been formed to help the Union reshape its membership structure and science education programs, establish Union awards and medals, and develop IUGG strategic planning.

- Affiliate membership of IUGG was established to strengthen cooperation with geoscientific organizations worldwide.

- Three Union Commissions - Data and Information, Climatic and Environmental Change, and Planetary Sciences - as well as the Union Working Group on History have been established to coordinate activities across IUGG associations and other international organizations on relevant scientific topics.

- IUGG established a new Grants Program to support interdisciplinary projects, which will explore new scientific ideas and develop future international initiatives.

- IUGG renewed its publication policy, and agreed to produce a series of works entitled "Special Publication of the IUGG" published by Cambridge University Press.

- The Union put forward a new initiative to enhance geophysical and geodetic science education centered on less affluent areas of the world and developed a fruitful cooperation with the Abdus Salam International Centre for Theoretical Physics. 
- IUGG established the honors program to recognize Earth and space scientists for their outstanding contributions to geodesy and geophysics and for unselfish international scientific cooperation.

Changes such as these enable the Union to do its best work in support of its mission, which is to continue to advance, strengthen and promote Earth and space sciences for the benefit of humanity, through international research cooperation and education, and to communicate the knowledge to governments and policy-makers (IUGG-SP, 2016). The application of Earth and space sciences to societal needs requires coordinated efforts between IUGG and other scientific bodies and stakeholders, including professional societies and intergovernmental organizations. IUGG will continue to evolve throughout the coming decades in step with the changing world of science and its international organizations, responding to the challenging problems of society.

Data availability. The paper is based on (i) published documents (see a list of references) as well as (ii) IUGG Archive documents. The original hard-copy documents of IUGG are deposited in the Niels Bohr Library and Archives of the American Institute of Physics (AIP, 2019). The documents are accessible only in the library with the permission of the IUGG Secretary General. 


\section{Appendix A}

Table A1. Member Adhering Bodies of IUGG (1919-2019).

\begin{tabular}{|c|c|c|c|c|c|}
\hline No. & Members & $\begin{array}{l}\text { Dates of admission } \\
\text { and termination }\end{array}$ & No. & Members & $\begin{array}{l}\text { Dates of admission } \\
\text { and termination }\end{array}$ \\
\hline 1 & Albania & 1997 & 51 & Korea & 1960 \\
\hline 2 & Algeria & 1971-2006, 2018 & 52 & Korea Dem. Rep. & $1967-2000$ \\
\hline 3 & Argentina & 1927 & 53 & Lebanon & $1967-2003$ \\
\hline 4 & Armenia & 2000 & 54 & Libya & 1979-1996 \\
\hline 5 & Australia & 1919 & 55 & Luxembourg & 1971 \\
\hline 6 & Austria & 1948 & 56 & Macedonia, F. Y. R. & 1995-2001, 2010 \\
\hline 7 & Azerbaijan & 2010 & 57 & Madagascar & $1967-1995$ \\
\hline 8 & Belgium & 1919 & 58 & Malaysia & $1967-2002$ \\
\hline 9 & Bolivia & 1960-2000, 2006 & 59 & Mauritius & 2003 \\
\hline 10 & Bosnia and Herzegovina & 2003 & 60 & Mexico & 1922 \\
\hline 11 & Brazil & 1922 & 61 & Monaco & $1967-2013$ \\
\hline 12 & Bulgaria & 1930 & 62 & Mongolia & $1995-2001$ \\
\hline 13 & Burundi & $1987-1995$ & 63 & Morocco & 1924 \\
\hline 14 & Canada & 1919 & 64 & Mozambique & 1983 \\
\hline 15 & Chile & 1924 & 65 & Myanmar (Burma) & $1957-2003$ \\
\hline 16 & China-CAST & 1977 & 66 & Nepal & $1975-1987$ \\
\hline 17 & China - Acad. Sci. in Taipei & 1995 & 67 & Netherlands & 1925 \\
\hline 18 & Colombia & $1938-1971,2000$ & 68 & New Zealand & 1927 \\
\hline 19 & Congo Dem. Rep. ${ }^{\mathrm{a}}$ & 1991-1997, 2004 & 69 & Nicaragua & 2014 \\
\hline 20 & Costa Rica & 2010 & 70 & Nigeria & 1971 \\
\hline 21 & Croatia & 1992 & 71 & Norway & 1923 \\
\hline 22 & Cuba & $1960-1996$ & 72 & Pakistan & 1952 \\
\hline 23 & Czech Rep. & 1993 & 73 & Peru & $1925-1979,2000$ \\
\hline 24 & Denmark & 1923 & 74 & Philippines & $1951-2015$ \\
\hline 25 & Dominican Rep. & $1957-1971$ & 75 & Poland & 1924 \\
\hline 26 & Egypt & 1924 & 76 & Portugal & 1919 \\
\hline 27 & Estonia & 1991 & 77 & Romania & 1930 \\
\hline 28 & Ethiopia & $1952-2000$ & 78 & Russia $^{b}$ & 1954 \\
\hline 29 & Finland & 1927 & 79 & Saudi Arabia & 1971-2001, 2012 \\
\hline 30 & France & 1919 & 80 & Senegal & $1960-1995$ \\
\hline 31 & Georgia & 2009 & 81 & Serbia $^{c}$ & 1996-2006, 2018 \\
\hline 32 & Germany & 1951 & 82 & Sierra Leone & $1967-1983$ \\
\hline 33 & Ghana & 1957-1987, 2006 & 83 & Slovak Rep. & 1993 \\
\hline 34 & Greece & $1922-2003,2008$ & 84 & Slovenia & 1994 \\
\hline 35 & Guatemala & $1957-2000$ & 85 & South Africa & 1924 \\
\hline 36 & Guinea & $1987-1995$ & 86 & Spain & 1922 \\
\hline 37 & Haiti & $1956-1971$ & 87 & Sudan & $1955-2000$ \\
\hline 38 & Hungary & 1930 & 88 & Sweden & 1923 \\
\hline 39 & Iceland & 1967 & 89 & Switzerland & 1923 \\
\hline 40 & India & 1947 & 90 & Syria & $1948-1995$ \\
\hline 41 & Indonesia & 1951 & 91 & Tanzania & $1975-2000$ \\
\hline 42 & Iran & 1957 & 92 & Thailand & 1923 \\
\hline 43 & Iraq & 1983-1996 & 93 & Tunisia & $1927-2001$ \\
\hline 44 & Ireland & 1946 & 94 & Turkey & 1949 \\
\hline 45 & Israel & 1951 & 95 & UK & 1919 \\
\hline 46 & Italy & 1919 & 96 & Uruguay & 1924-2000, 2019 \\
\hline 47 & Ivory Coast & 1975-1996 & 97 & USA & 1919 \\
\hline 48 & Japan & 1919 & 98 & Venezuela & $1975-2008$ \\
\hline 49 & Jordan & 1979 & 99 & Vietnam & 1931 \\
\hline 50 & Kenya & $1975-1997$ & 100 & Zimbabwe & $1967-2000$ \\
\hline
\end{tabular}

a Admission in 1991 under the name Zaire; membership terminated in 1997. ${ }^{\mathrm{b}}$ Admission in 1954 under the name of the USSR; Russia since 1992. ${ }^{c}$ Admission in 1996 under the name of the Fed. Rep. of Yugoslavia which was changed to Serbia and Montenegro in 2003, and changed to Serbia in 2018 
Appendix B

Table B1. IUGG timeline (1919-2019).

\begin{tabular}{|c|c|c|}
\hline Year & Activity & Place \\
\hline 1919 & $\begin{array}{l}\text { IUGG was founded with six Sections (Geodesy, Terres- } \\
\text { trial Magnetism and Electricity, Meteorology, Physical } \\
\text { Oceanography, Seismology, and Volcanology) }\end{array}$ & Brussels, Belgium \\
\hline 1922 & Seventh Section, Scientific Hydrology, was added & Rome, Italy \\
\hline $1932 / 1933$ & The Second International Polar Year & \\
\hline 1933 & Sections were renamed International Associations & Lisbon, Portugal \\
\hline 1946 & $\begin{array}{l}\text { Extraordinary General Assembly to reconstitute IUGG } \\
\text { following WWII }\end{array}$ & Cambridge, UK \\
\hline 1946 & $\begin{array}{l}\text { IUGG and U.N. Education, Scientific and Cultural Or- } \\
\text { ganization (UNESCO) signed a working agreement }\end{array}$ & Paris, France \\
\hline 1951 & $\begin{array}{l}\text { The International Association (IA) of Seismology be- } \\
\text { came the IA of Seismology and Physics of the Earth's } \\
\text { Interior (IASPEI) }\end{array}$ & Brussels, Belgium \\
\hline 1952 & $\begin{array}{l}\text { First issue of the IUGG Bulletin, which became the } \\
\text { IUGG Chronicle (ceased in 1995) }\end{array}$ & \\
\hline 1954 & $\begin{array}{l}\text { IUGG and the World Meteorological Organization } \\
\text { (WMO) signed a working agreement }\end{array}$ & Geneva, Switzerland \\
\hline $1957 / 1958$ & The International Geophysical Year (IGY) & \\
\hline 1957 & $\begin{array}{l}\text { The IA for Terrestrial Magnetism and Electricity be- } \\
\text { came the IA for Geomagnetism and Aeronomy (IAGA) }\end{array}$ & Toronto, Canada \\
\hline 1960 & $\begin{array}{l}\text { Cooperation with the Intergovernmental Oceanographic } \\
\text { Commission of UNESCO started }\end{array}$ & Paris, France \\
\hline 1967 & First use of the present day IUGG logo & Zurich, Switzerland \\
\hline 1967 & $\begin{array}{l}\text { The IA of Volcanology became the IA of Volcanology } \\
\text { and Chemistry of the Earth's Interior (IAVCEI) }\end{array}$ & Zurich, Switzerland \\
\hline 1967 & $\begin{array}{l}\text { The IA of Physical Oceanography became the IA for } \\
\text { the Physical Sciences of the Ocean (IAPSO) }\end{array}$ & Zurich, Switzerland \\
\hline 1971 & $\begin{array}{l}\text { The IA of Scientific Hydrology became the IA of Hy- } \\
\text { drological Sciences (IAHS) }\end{array}$ & Moscow, USSR (now Russia) \\
\hline 1971 & $\begin{array}{l}\text { The Inter-Association Committee on Mathematical } \\
\text { Geophysics (now the Union Commission on Mathemat- } \\
\text { ical Geophysics - CMG) was established }\end{array}$ & Moscow, USSR (now Russia) \\
\hline 1975 & $\begin{array}{l}\text { Cooperation with the International Hydrological Pro- } \\
\text { gram of UNESCO started }\end{array}$ & Paris, France \\
\hline 1987 & $\begin{array}{l}\text { Union Committee on the Study of the Earth's Deep In- } \\
\text { terior (now the Union Commission SEDI) was estab- } \\
\text { lished }\end{array}$ & Vancouver, Canada \\
\hline 1988 & $\begin{array}{l}\text { The first International Terrestrial Reference Frame is re- } \\
\text { leased by the IAG }\end{array}$ & \\
\hline 1991 & $\begin{array}{l}\text { The International Lithosphere Program becomes an } \\
\text { IUGS/IUGG inter-Union body }\end{array}$ & Vienna, Austria \\
\hline 1995 & $\begin{array}{l}\text { The International Association of Meteorology and At- } \\
\text { mospheric Physics (IAMAP) becomes the IA of Mete- } \\
\text { orology and Atmospheric Sciences (IAMAS) }\end{array}$ & Boulder, USA \\
\hline 1998 & IUGG website established & \\
\hline
\end{tabular}


Table B1. Continued.

\begin{tabular}{|c|c|c|}
\hline Year & Activity & Place \\
\hline 2000 & $\begin{array}{l}\text { Union Commission on Geophysical Risk and Sustain- } \\
\text { ability (GRC) was established }\end{array}$ & \\
\hline 2001 & IUGG monthly E-Journal established & \\
\hline 2003 & $\begin{array}{l}\text { Early Career Scientist Union Symposium series was es- } \\
\text { tablished }\end{array}$ & Sapporo, Japan \\
\hline 2004 & ICSU GeoUnions consortium was established & Paris, France \\
\hline 2007 & $\begin{array}{l}\text { International Association for Cryospheric Sciences was } \\
\text { established }\end{array}$ & Perugia, Italy \\
\hline 2008 & The IUGG Grants Program was established & \\
\hline $2007 / 2008$ & $\begin{array}{l}\text { The Electronic Geophysical Year (eGY) } \\
\text { The International Heliophysical Year (IHY) } \\
\text { The International Year of Planet Earth (IYPE) } \\
\text { The International Polar Year (IPY) }\end{array}$ & \\
\hline 2008 & $\begin{array}{l}\text { The Union Commission for Data and Information } \\
\text { (UCDI) was established }\end{array}$ & \\
\hline 2011 & $\begin{array}{l}\text { IUGG and the Abdus Salam International Centre for } \\
\text { Theoretical Physics (ICTP) agreed to develop a joint } \\
\text { geophysical and geodetic science education program }\end{array}$ & Trieste, Italy \\
\hline 2011 & $\begin{array}{l}\text { Affiliate Membership and Honorary Membership were } \\
\text { established }\end{array}$ & Melbourne, Australia \\
\hline 2012 & $\begin{array}{l}\text { The Union Commission on Climatic and Environmental } \\
\text { Change (CCEC) was established }\end{array}$ & \\
\hline 2012 & The Working Group on History was established & \\
\hline 2012 & $\begin{array}{l}\text { IUGG signed a Memorandum of Agreement with the } \\
\text { Cambridge University Press to publish a series of works } \\
\text { entitled "Special Publications of the IUGG" }\end{array}$ & \\
\hline 2013 & $\begin{array}{l}\text { IUGG became a Participating Organization of the } \\
\text { Group on Earth Observations (GEO) }\end{array}$ & Geneva, Switzerland \\
\hline 2015 & $\begin{array}{l}\text { First IUGG Awards (Gold Medal, Silver Medal, IUGG } \\
\text { Fellows, and Early Career Scientist Award) presented }\end{array}$ & Prague, Czech Republic \\
\hline 2015 & $\begin{array}{l}\text { The Union Commission on Planetary Sciences (UCPS) } \\
\text { was established }\end{array}$ & \\
\hline 2016 & New Association logos designed and approved & \\
\hline 2016 & $\begin{array}{l}\text { Strategic Plan 2016-2023 and its Implementation Plan } \\
\text { were adopted }\end{array}$ & \\
\hline 2017 & $\begin{array}{l}\text { IUGG became an Observer Organization of the Inter- } \\
\text { governmental Panel on Climate Change (IPCC) }\end{array}$ & Geneva, Switzerland \\
\hline 2019 & IUGG Centennial & Montreal, Canada \\
\hline
\end{tabular}


Author contributions. JAJ and AIZ contributed equally to the analysis and writing the paper; other co-authors contributed to the analysis of specific chapters of the paper; and AIZ prepared the manuscript for publication.

Competing interests. The authors declare that they have no conflict of interest.

Special issue statement. This article is part of the special issue "The International Union of Geodesy and Geophysics: from different spheres to a common globe" (https://www.hist-geo-space-sci. net/special_issue $996 . h t m l)$. It is not associated with a conference.

Acknowledgements. The authors are thankful to Jaime UrrutiaFucugauchi, Aksel W. Hansen, and Kristian Schlegel (topic editor) for the review of the paper and their comments.

Edited by: Kristian Schlegel

Reviewed by: Jaime Urrutia-Fucugauchi and Aksel Walloe Hansen

\section{References}

Adams, J.: The fourth age of research, Nature, 497, 557-560, 2013. AIP: Records of the International Union of Geodesy and Geophysics, 1922-2000 (bulk 1955-1998), Description of collection, American Institute of Physics, Center for History of Physics, 2019, available at: https://history.aip.org/ead/20010000. html (last access: 16 January 2019).

Ashford, O. M.: The launching of the Global Atmospheric Research Programme (GARP), Weather, 37, 265-272, 1982.

Beer, T., Li, J. and Alverson, K. (Eds.): Global Change and Future Earth: The Geoscience Perspective, Cambridge University Press, Cambridge, 2018.

Bolin, B.: A History of the Science and Politics of Climate Change: The Role of the Intergovernmental Panel on Climate Change, Cambridge University Press, Cambridge, 2007.

Cartlidge, E.: Italy's supreme court clears L'Aquila earthquake scientists for good, Science, https://doi.org/10.1126/science.aad7473, 2015.

Cutter, S., Ismail-Zadeh, A., Alcántara-Ayala, I., Altan, O., Baker, D. N., Briceño, S., Gupta, H., Holloway, A., Johnston, D., McBean, G. A., Ogawa, Y., Paton, D., Porio, E., Silbereisen, R. K., Takeuchi, K., Valsecchi, G. B., Vogel, C., and Wu, G: Pool knowledge to stem losses from disasters, Nature, 522, 277-279, 2015.

Ismail-Zadeh, A.: Geoscience international: the role of scientific unions, Hist. Geo Space Sci., 7, 103-123, https://doi.org/10.5194/hgss-7-103-2016, 2016.

Ismail-Zadeh, A.: Mapping IUGG to Sustainable Development Goals, IUGG E-Journal, 16, 8-10, 2016.

Ismail-Zadeh, A. T. and Beer, T.: International cooperation in geophysics to benefit society, Eos, 90, 501-502, 2009.

Ismail-Zadeh, A. and Cutter, S. (Eds.): Disaster Risks Research and Assessment to Promote Risk Reduction and Management, Inter- national Council for Science and the International Social Sciences Council, Paris, France, 2015.

Ismail-Zadeh, A. and Joselyn, J. A.: IUGG: beginning, establishment, and early development (1919-1939), Hist. Geo Space Sci., 10, this special issue, available at: https://www. hist-geo-space-sci.net/special_issue996.html, 2019.

Ismail-Zadeh, A., Urrutia Fucugauchi, J., Kijko, A., Takeuchi, K., and Zaliapin, I. (Eds.): Extreme Natural Hazards, Disaster Risks and Societal Implications, Cambridge University Press, Cambridge, 2014.

Ismail-Zadeh, A., Cutter, S. L., Takeuchi, K., and Paton, D.: Forging a paradigm shift in disaster science, Nat. Hazards, 86, 969-988, 2017.

IUGG Archives: Resolutions of the Union adopted at the XXIII General Assembly, Sapporo, Japan, available at: http: //www.iugg.org/resolutions/sapporo03.pdf (last access: 16 January 2019), 2003.

IUGG Archives: Resolutions of the Union adopted at the XXIV General Assembly, Perugia, Italy, available at: http://www.iugg. org/resolutions/perugia07.pdf (last access: 16 January 2019), 2007.

IUGG Archives: Resolutions of the Union adopted at the XXV General Assembly, Melbourne, Australia, available at: http://www.iugg.org/resolutions/ IUGGResolutions-XXVGA-Melbourne(English).pdf (last access: 16 January 2019), 2011.

IUGG Archives: Resolutions of the Union adopted by the Council at the XXVI General Assembly, Prague, Czech Rep., available at: http://www.iugg.org/resolutions/IUGGResolutions2015.pdf (last access: 16 January 2019), 2015.

IUGG-SP: IUGG Strategic Plan 2016-2023, available at: http:// www.iugg.org/special/IUGG_StrategicPlan_2016-2023.pdf (last access: 14 October 2018), 2016.

IUGG-IA: Implementation Actions for the IUGG Strategic Plan 2016-2023, available at: http://www.iugg.org/special/IUGG_ ImplementationActions4SP.pdf (last access: 14 October 2018), 2017.

Joselyn, J. A., and Ismail-Zadeh, A.: IUGG evolves (1940-2000), Hist. Geo Space Sci., 10, this special issue, available at: https: //www.hist-geo-space-sci.net/special_issue996.html, 2019.

Kontar, Y. Y., Beer, T., Berkman, P. A., Eichelberger, J. C., Ismail-Zadeh, A., Kelman, I., LaBrecque, J. L., Sztein, A. E., and Zaika, Y.: Disaster-related science diplomacy: advancing global resilience through international scientific collaborations, AAAS Science and Diplomacy, 7, available at: http://www.sciencediplomacy.org/article/2018/disasterrelated-science-diplomacy-advancing-global-resilience-through -international (last access: 29 January 2019), 2018.

Li, J., Swinbank, R., Grotjahn, R., and Volkert, H. (Eds.): Dynamics and Predictability of Large-Scale, High-Impact Weather and Climate Events, Cambridge University Press, Cambridge, 2016.

NAS: Facilitating Interdisciplinary Research. Report of the Committee on Facilitating Interdisciplinary Research of the National Academies, National Academies Press, Washington D.C., 2004.

Rohde, H.: Bert Bolin (1925-2007) - a world leading climate scientist and science organiser, Tellus B, 65, 1-6, 2013.

Sparks, R. and Hawkesworth, C. (Eds.): The State of the Planet: Frontiers and Challenges in Geophysics, American Geophysical Union, Washington D.C., 2004. 
UN: Transforming our World: The 2030 Agenda for Sustainable Development, A/RES/70/1. United Nations, New York, available at: https://sustainabledevelopment.un.org/index.php? page $=$ view $\&$ type $=111 \& \mathrm{nr}=8496 \&$ menu $=35$ (last access: 16 January 2019), 2015.

Weart, S. R.: The evolution of international cooperation in climate science, Journal of International Organizations Studies, 3, 41-59, 2012.
Williamson, P., Smythe-Wright, D., and Burkill, P. (Eds.): Future of the Ocean and its Seas: a non-governmental scientific perspective on seven marine research issues of G7 interest. ICSUIAPSO-IUGG-SCOR, Paris, available at: http://www.iugg.org/ policy/Report_FutureOcean_G7_2016.pdf (last access: 14 October 2018), 2016. 